\title{
The Effect of Asset- Liability Management on Profitability of Private Commercial Banks in Ethiopia
}

\author{
Tesfaye Eresso Gofe \\ Assistant Professor, Department of Accounting and Finance; College of Business and Economics; Wollega \\ University; Nekemte; Ethiopia \\ Ifa Akuma Fayisa \\ Lecturer, Department of Accounting and Finance, College of Business and Economics, Wollega University, \\ Nekemte, Ethiopia
}

\begin{abstract}
This research was conducted to investigate the effect of asset liability management on profitability of private commercial banks in Ethiopia by using panel data of seven private commercial banks in Ethiopia from year 2005 to 2017 G.C.The study used audited annual financial report of selected banks and analyzed by using multiple regression models moreover, net interest income, was to measure profitability.Fixed effect regression model was applied to investigate the effects of Asset Liability factors on banks, by employing statistical Cost Accounting model for the sampled banks. To conduct the study quantitative research method was employed and explanatory research design was used in trying to establish the causal effect relationship between profitability and asset liability management variables The study utilized panel data analysis methodology in attest conclusions about the effect of the explanatory variables on the dependent variable. The study revealed that loan and advances, deposit in foreign banks, and investment in security had a statistically significant and positive except loan and advance effect on net interest income, whiledemand deposit had a statisticallysignificant positive effect on net interest income. Whereas saving deposit and fixed deposit from the liability part, don't have statistically significant positive effect on profitability as measured by net interest income. Therefore, Bank managers are advised to give due attention to the statically significant positive variables (I.e, deposit in foreign bank, investment in security) to Improve profitability.

Keywords:-Profitability, Private commercialbanks, asset liability management, Ethiopia
\end{abstract}

DOI: $10.7176 /$ RJFA/11-9-04

Publication date:May $31^{\text {st }} 2020$

\section{INTRODUCTION}

The financial system consists of a variety of institutions, markets and instruments. It provides the principal way by which saving are changed in the earning investments. Given its significant role in the allocation resources the efficient functioning of the financial system is a vital importance to a modern economy (Chandra, 2003). One of the main objectives of financial institution is mobilizing resources and channeling them to the investors. This channeling role of financial institutions takes different forms in different economic systems (Alemayehu, 2006).According to Somashekar (2009) Commercial banks are considered not only as dealers in money but also act as the leaders in economic development. They are not only the stock up houses of the country's funds but also the reservoirs of resources necessary for economic development. They play a significant role in the economic development of a country.

Commercial banks are among the financial intermediaries that raise funds, as traditionally perceived, primarilyby issuing checkable/demand deposits, saving deposits, and time/fixed deposits(Mishikin, 2004). Because thefinancial system in our country is at its kidding stage, commercial banks are also authorized to provide all thebanking service in the financial market. Since there is no well organized financial market, almost all of thetransactions and activities of money and capital market are carried out by the commercial banks.

According to Roy (2010) Commercial banks today are important not only from the view of economic growth, but also financial stability of the country. In developing economies, banks are particular for three important reasons. First, they take a most important role in developing other financial intermediaries and markets. Second, due to the absence of strong bond markets and equity markets, the corporate sector and investors depends heavily on banks to meet its financing needs. Finally, in developing markets or underdeveloped countries markets banks provide to the needs of a vast number of savers from the household, who wish to secure income and liquidity and safety of funds, because of their inadequate capacity to manage financial risks in general.

As Mishikin (2004) shows, a commercial bank's liability which is mainly financed by current, saving, and fixed deposits and equity (which is contributed by shareholders) represent its sources of funds; while asset which is composed of mainly investments, loans and advances represent its use of funds. Given the legal requirements of commercial banks, each commercial bank determines its own composition of liabilities and assets, which 
determines its specific operating objective; maximizing shareholders equity (profit).

Profitability is a measure of economic gains realized by a firm in relation to the capital invested. This level of economic success can be determined by the amount of reported profits in a fiscal year. Zopounidis,[ 2001] stated that business environment is characterized by risks and uncertainties to effectively compete in the market place banks manage their assets and liabilities taking into consideration the risk level, earnings, liquidity, profit, solvency, the level of loans and deposits to mitigate losses and thus improve profitability. Since asset liability management plays a critical role in risk management, it is imperative that banks recognize the asset liability importance and apply effective risk management procedures; Effective implementation of advanced asset liability management techniques allows banks to hedge the risk and to maximize Profitability in today's highly competitive markets for banking services.

Asset liability management enables a firm to balance between its liabilities and assets. This in turn minimizes financial risks and hence improves profitability. Asset liability management guides a firm in making investment decision. This is because the firm is able to allocate sufficient funds for investment as a result of adoption of liquidity management best practices and argue that firms that maintain a proper structure of their balance sheet records high profitability compared to those firms who fail to maintain proper balances of assets and liabilities, this is achieved by effective risk management which play an integral role in addressing financial risk since all risk cannot be eliminated but it is the responsibility of risk managers to identify their risk levels and know which level can be controlled or accepted(Uyemura and Van Deventer, 2003).

Various authors reveal that the variables that are directly related to the bank's asset liability management (i.e. loans to assets ratio, and foreign bank to asset ratio, investment to asset ratio, customer deposit to asset ratio) are those which mostly affect banks profitability. And also agree on non management controllable such as macro-economic variable and market concentration has a significant effect on banks net earnings. Their findings showed that Asset, macro-economic andmarket concentration factors has a positive impact and liability have a negative impact on banks profitability(Sayeed\&Hoqve, 2008 and Nasif, 2010).

The main issue of ALM is the bank's balance sheet and the main question is: given a certain level of risk, government regulation, globalization, competitors, and alternative choices of investment, and liquidity and interest rate changes in the market, what should be the composition of a bank's assets and liabilities in order to maximize the bank's profit? What should be the optimal combination of ALM? These are the two questions raised by Kosmidou(2005) who argued that the optimal balance between these factors cannot be found without considering important interactions that exist between the structure of a bank's liability and capital and the compositions of its assets. Therefore, the assets and liabilities of commercial banks shall be managed in order to maximize shareholder value, to enhance profitability and increase capital, to serve customer and community needs, and to protect the institution from any disastrous financial consequences arising from different changes.

In order to cope up with the changes in the environment, the Ethiopian banking industry has became competitive and have been forced to effectively manage their asset and liability to mitigate various risks that arise due to mismatch between their assets and liabilities.Asset liability management is the heart bit of the financial institution specially banks with the aim to reduce the risks of the banks and maximizing total revenue (Faruk, 2014). Banks Profitability depends on the skills of the management to deal sharply and successfully with asset and liability to tide over risks and uncertainties through shifting them or hedging benefits (Kavitha, 2012). According to Litiekiene (2008) ALM is very important for commercial banks to accept such strategy that would reduce the default risk, interest rate risk and would stabilize the risk, profitability, liquidity and safety.

The asset measure of bank profitability and efficiency are affected by both internal and external factors. Various studies attest to this fact (Balachander,1997, Ramlall, 2009, Alper and Anbar, 2011). Internal factors are related to bank management which encompasses the ALM culture of the bank and external determinants are factors which reflect the macroeconomic and legal environment that affect the operation and performance of commercial banks.

The traditional ALM programs focus on interest rate risk and liquidity risk because they represent the most prominent risks affecting the organization balance-sheet (as they require coordination between assets and liabilities). But ALM also now seeks to broaden assignments such as foreign exchange risk and credit risk; however the main objective of ALM is not to eliminate risk. Rather, it is to manage risks within a framework that includes self imposed limits.

Nonetheless, in the context of Ethiopian banking industry, the subject has received a limited research attention. In which case, in order to either prove the above premises or reach into some other assertion regarding the relationship between asset liability management and Profitability of

Ethiopian banking sector, empirical investigation is lacking. As far as the knowledge of the researcher is concerned, there are a few researches related toasset liability management and Profitability in Ethiopian banking industry (Tamiru,2013 ). Among asingle studies corresponding with this research is that, the research conducted by Tamir (2013) has used eight independent variables includes deposit in other banks, other investment and debit balance, loan and advance ,fixed assets ,saving deposit ,demand deposit ,fixed deposit, real gross domestic 
product and inflation. However, the researcher did not incorporate the variable like market concentration and did not use the measurement of the core business operation as the dependent variable (I.e. NIM).

Most of previous studies conducted to test the relationship between ALM and profitability using comprehensive measures of profitability return on asset (ROA) and return on equity (ROE), no one was emphasized on the core business operations profitability of banks. For the purpose of this study core business operation of commercial banks was defined as the banks' operations of deposit mobilization and providing loans to customers. Hence, didn't take into account other measures of profitability particularly the measure of profitability for core business operations of banking sector, net interest income(NII).

Nevertheless, study goes further to include other variables influencing Profitability with relation to ALM targeted factors are loan and advances, deposit in foreign bank, investment in securities, Fixed deposit, saving deposit, demand deposit their effect on Profitability of private commercial banks in Ethiopia. In order to bridge this gap this research is aimed at analyzing the effects of Asset Liability Management on profitability of commercial banks and making such a study contextually relevant and prospectively significant in Ethiopia.

The general objective of the study is to investigate the effects of asset liability management on profitability of privatecommercial banks in Ethiopia.Specifically the study was aimed to analyze the effects of earning asset on profitability of private commercial banks in Ethiopia, and to analyze the effects of liabilities side on profitability of private commercial banks in Ethiopia.

In line with the broad purpose statement the following hypotheses were also formulated for investigation. Hypotheses of the study stands on the theories and past empirical studies related to profitability and Asset Liability Management. The results from the literature review were used to establish expectations for the relationship of the different determinants. Hence, based on the objective, the present study seeks to test the following hypotheses:

H1: $\quad H_{a l}$ Loan and advances positively affect Bank profitability.

H2: $\quad H_{a l}$ Deposit in foreign bank positively affects Bank profitability.

H3: $\quad H_{a I}$ Investmentin security positively affects Bank profitability.

H4: $\quad H_{a l}$ Fixed depositnegatively affects Bank profitability.

H5: $\quad H_{o 1}$ Saving deposit negatively affects Bank profitability

H6: $\quad H_{a l}$ Demand deposit positively affects Bank profitability.

It is important to define the boundaries of the study that the readers will be aware of the direction to which this study is heading. The study is highly contemplated on the broadest of risk management techniques which is asset liability management despite that the topic of this study delimited to investigating the asset liability management factors such as loan and advance, deposit in foreign banks,investiment in security, fixed deposit, saving deposit, demand deposit,affecting the profitability of all private commercial banks registered by the NBE and by taking evidence for the period ranging from 2005 to 2017.As a result, it includes the seven private commercial banks in the country namely, Awash International Bank, Dashen Bank, Bank of Abyssinia, Wegagen Bank, United Bank, Nib International Bank and Cooperative Bank Of Oromia.

\section{EMPIRICAL EVIDENCES ON BANKS PRofitabiLITy}

Various researches disclosed that internal factors significantly affect the asset measures of bank profitability which actually measures management efficiency employing the available resources to generate profit (Balachander, 1997). According to Ramlall (2009) and Alper and Anbar (2011) bank profitability can be affected by both internal and external factors. Internal factors are related to bank management which encompasses the ALM culture of the bank and external determinants are factors which reflect the economic and legal environment that affect the operation and performance of commercial banks.

Various authors reveal that the variables that are directly related to the bank's asset liability management (i.e. loans to assets ratio, deposit in local and foreign bank to asset ratio, investment to asset ratio, customer deposit to asset ratio) are those which mostly affect banks profitability. They also agreed on non management controllable such as macro-economic variables and market concentration has a significant impact on banks net earnings. They arriving conclusion like Asset, macro-economic factors and market concentration has a positive effect and liability have a negative effect on banks profitability (Sayeed\&Hoqve 2010 and Nasif, 2010). In Ethiopia, recent finding shows that Assethave a positive impact and liability have a negative effect on the profitability of banks (Tamiru, 2013).

As we seen in theoretical literature banks generate survival income from its advancing loans. Empirical study reveals that loans and advances significantly affect commercial banks profitability. According to Gul, Irshad and Zaman (2011) Having too much loans shows the chances of rising banks return on assets. Alper and Anbar (2011) study reflects that the ratios of loans to assets are found negative and significant impacts on ROA. Flamin, McDonald and Schumacher (2009)conclude that credit portfolio volume and weak asset quality affect negatively return on asset. Bank loans are expected to be the main source of income and are expected to have a positive impact on bank performance. 
Muhammad \& Mohammad (2009), in their application of SCA to assess ALM impact on profitability they recognized that Private commercial Banks are better than public banks in terms of asset management, but they do not have any superiority over public banks in terms of liability management. This does not provided them conclusive support that ALM in private banks is superior to ALM in public banks. Thus, study could not explain the profitability differences between these two sets of banks through analyzing ALM. Their study considered the market concentration index and GDP growth rate, unlike the previous ones.

Muhammad and Mohammad (2009) measured profitability by assuming two levels of measures of income: total income and net operating income.

There are many asset-liability management models in the practice. Looking to the past, the first mathematical models in the field of bank management are found. Asset and liability management models can be deterministic or stochastic (Kosmidou and Zopounidis, 2001). Deterministic models use linear programming, assume particular realizations for random events, and are computationally tractable for large problems. The deterministic linear programming model of Chambers and Charnes (1961) is the pioneer in ALM. Chambers and Charnes were concerned

Mulvey and Vladimirou (1992) used dynamic generalized network programs for financial planning problems under uncertainty and they developed a model in the framework of multi-scenario generalized network that captures essential features of various discrete time financial decision problems.

Mulvey and Ziemba (1998) present a more detailed overview of various asset and liability modeling techniques, including models for individuals and financial institutions such as banks and insurance companies.

Moreover, over the years, many models have been developed in the area of financial analysis and financial planning techniques. Kvanli (1980), Lee and Lerro (1973), Lee and Chesser (1980),

Baston (1989), Sharma et al. (1995), among others have applied goal programming to investment planning. Booth et al. (1989), Giokas and Vassiloglou (1991), Seshadri et al. (1999) presented bank models using goal programming.

Hester \&Zoellner (1966) employed statistical cost accounting (SCA) model on US banks. Mihir\& Ravi (2009) implemented the canonical analysis to assess the nature of relationship between assets and liabilities setting the hypothesis assets influence liabilities. This method was also used by Seem Jawal (2010), who found that strong canonical correlation between asset and liability accounts, indicating high asset-liability dependency and the canonical correlation in each sector (pubic, private and foreign banking sectors ) of banks in India under study declined from the period 1997-2000 to 2005-2008.

\section{VARIABLES SUMMARY \& HYPOTHESIS FORMULATION}

Most of the empirical investigations on ALM consider the effect of ALM and other macroeconomic factors on profitability. This section conducted to demonstrate the relationships existing between profitability and ALM along with other factors through developing a testable hypothesis. The study conducts a regression assuming Net Interest Income as a measure of profitability. The variables considered are; assets, liabilities, inflation, GDP growth rate, and Market share.

\subsection{Asset}

Bank balance sheet assets are earning items. According to Kwast and Rose (1992) when total income is used as measure of profitability, assets directly contribute in increasing in marginal rate of return which in turn increases total income. Even, when net income is used as a profit measure a net return from assets is still positive. The SCA model adopted by Hester and Zoellener (1966) marks a positive relationship between assets and profitability of a bank. Based on the nature of assets and SCA model the researcher hypothesizes that:

HYPOTHESIS ONE: THERE IS A POSITIVE RELATIONSHIP BETWEEN ASSETS AND NET INTEREST INCOME.

\subsection{LIABILITIES}

Liabilities are reasons for incurring costs. These liabilities emerge from deposits and other borrowings. Since it is customary that banks impose service charges on deposit accounts and nonother deposit liabilities, the return on liability should be positive (Muhammad and Mohammed, 2009). This holds true so long as total income is taken. When the net counterpart is taken, a liability's marginal cost is deemed. Apparently; operating costs are generally higher thantheservice charges earned from deposits, which would signify a negative return of liabilities (Muhammad and Mohammed, 2009,). Thus, based on this the researcher hypothesizes that:

Hypothesis two: There is a negative relationship between liabilities and net interest income

\section{Conceptual Framework}

Conceptual framework as a framework that is structured from a set of broad ideas and theories that help a researcher to properly identify the problem they are looking at frame their questions and find suitable literature (Smyth ,2004) .Conceptual framework of the study consist of independent variables; loan and advance ,deposit 
in foreign banks, investment in security, fixed deposit ,saving deposit ,demand deposit and dependent variable; Profitability(NIM), Based on the insights gained from review of the literature, the following conceptual Framework showing the relationship between asset liability management variable and Profitability was created.

\section{Figure 4.1: ConCEPTUAl Frame WORK \\ Bank asset}

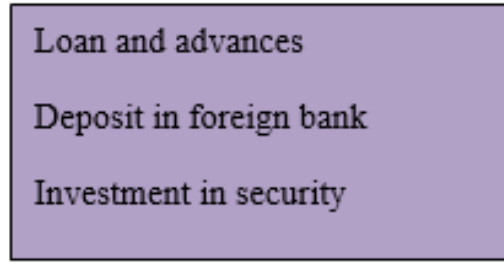

\section{Bank Liability}

Fixed deposit

Saving deposit

Demand denosit

\section{Bank profitability} (NIM)

Net interest margin

Source:Developed by Researcher

\section{RESEARCH DESIGN ANDMETHODOLOGY}

\subsection{RESEARCH DESIGN}

The study adopts explanatory and quantitative research type. The purpose of explanatory research describes cause and effect relationship of dependent and independent variables and was make it suitable for this study because the researcher was fairly knowledgeable about the aspects of the phenomenon, but little is known regarding their nature. The study was also guide by pure quantitative research approach.

\subsection{Method of DATA COLlection}

The secondary data was gathered from the national bank of Ethiopia by the researcher. The collected data was readily computed to express the study independent and dependent variable from the collected financial statement through the theoretical concept of each variable calculation.

\subsection{VARIABLE DESCRIPTION}

\subsubsection{DEPENDENT VARIABLE}

Profit is the ultimate goal of Private commercial banks. All the strategies designed and activities performed thereof are meant to realize this grand objective. However, this does not mean that private commercial banks have no other goals. Private Commercial banks could also have additional social and economic goals. However, the intention of this study is related to the first objective, profitability. To measure the profitability of private commercial banks there are variety of measures used of which total income, net Income and net interest income Alexandru (2008).

Net interest income is interest income minus interest expense. Interest income: interest earned on loans, deposits held at other institutions, and securities. Interest Expense: interest paid on deposits, other borrowings, and notes and debentures.In this research going to measure banks profitability by using the net-interest income measures by conducting a multivariate regression for the dependent variable.

\subsubsection{INDEPENDENT VARIABLE}

\subsubsection{ASSETS}

This study accounts the book value of assets. Because, notes to the financial statements of banks excerpt that financial statements are prepared in accordance with the historical cost convention. Average variable are computed by adding beginning and ending book values and dividing bytwo. These values are further divided by average total assets of the year to express them in ratios for the same period. Explanatory variable assets are described in the following table. 


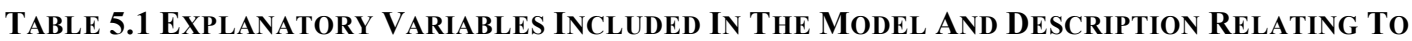
PCBS'ASSETS

\begin{tabular}{|l|l|}
\hline Assets & \\
\hline Variables & Description \\
\hline NLATA & Loan and advance \\
\hline DFBATA & Deposit in foreign banks \\
\hline IVEATA & Investment in security (i.e. short-term inv. + equity inv. + other inv.) \\
\hline
\end{tabular}

In a case of variable IVEATA the researcher decided to use aggregated accounts instead of individual accounts that are shown in brackets. Disaggregating these variables and entering the individual accounts into equation, would introduce many zero values, which could distort our result.

\subsubsection{LIABILITIES}

Like the assets counter parts liabilities figures show book values. Averages are taken and then are divided for average total assets to come with ratios. Liabilities included from the balance sheet are described in the subsequent table.

TABLE 5.2 EXPLANATORY VARIABLE AND DESCRIPTIONS RELATING TO PCB'S LIABILITIES

\begin{tabular}{|l|l|}
\hline Liability & Description \\
\hline Variables & Fixed deposit \\
\hline FDATA & Saving deposit \\
\hline SDATA & Demand deposit \\
\hline DDATA
\end{tabular}

\subsection{DATA ANALYSIS TECHNIQUES}

The statistical cost accounting (SCA) multivariate model will be employed to figure out the effect of explanatory variables on the dependent variable. The study will conduct three multivariate regressions for banks, assuming, net income and net interest income. After the necessary data was collected, "STATA 13" software program was used for data process. The data processed was be presented by the use of tables and words. Data was analyzed using descriptive statistical techniques like mean, standard deviation, minimum and maximum. The correlation analysis is also used. The statistical cost accounting model explained above was also adopted to provide the major finding.

\subsection{MODEL SPECIFICATION}

In order to test the research hypothesis and investigate relationship between variables multiple regression model were used.

Modeling is based on panel data techniques. Comprises of both cross sectional elements and time series elements; the cross sectional element is reflected by the seven (7) private banks and thetime series element is reflected the period of study (2005-2017). Panel data is favored over time series or cross sectional data because it can control for individual heterogeneity and there is a less degree of multi-linearity between variables (Altai, 2005).

The traditional model (Hester and Zoellenr, 1966) suggests an equation for showing the variations in banks net income, Ybt expressed for bank $b$ and time $t$ in terms of variations of assets and liabilities in the following way:

$\mathrm{Ybt}=\alpha 1+\Sigma \alpha 2 \mathrm{iAibt}+\Sigma \alpha 3 \mathrm{jLjbt}+\mathrm{ebt}$

Where,

$\mathrm{Ai}=$ Ith asset.

$\mathrm{Lj}=$ jth liability.

$\alpha 1=$ net fixed income that is not dependent on assets and liabilities.

ebt $=$ error term.

$\alpha 2 \mathrm{i}=$ marginal rate of return on assets.

$\alpha 3 \mathrm{j}=$ marginal cost of liabilities

As the banks have wide variations in their business volume, all variables of equation (1) are divided by a banks average total asset (ATAbt) (kosmidouet al., 2004). Thus equation (1) takes the form of:

$\mathrm{Ybt} / \mathrm{ATAbt}=\alpha 1 / \mathrm{ATAbt}+\Sigma \alpha 2 \mathrm{i}$ Aibt $/$ ATAbt $+\Sigma \alpha 3 \mathrm{jLjbt} /$ ATAbt + ebt+............................................ (2)

Where, the stochastic term ubt $=$ ebt/ ATAbt

The structure of the traditional SCA model ignores macroeconomic variables.

All assets and liabilities were not being included as independent variables in the model. This was done to avoid prefect co linearitywithin the independent variables. Hence, cash and fixed assets on the assets side and equity capital on the liabilities side will be excluded from the model (Muhammad and Mohammad, 2009). 


\section{DATA ANALYSIS AND INTERPRETATIONS}

This chapter deals with the results and analysis of the findings and it contains three sections. The first section presented descriptive and correlation analysis on variables of the study; these condsection presented fulfillment of the classical linear regression model (CLRM) assumptions; the third section laid down the results of regression of this study.

\subsection{RESULTS OF THE REGRESSION ANALYSIS}

As stated in Brooks (2008), in financial research, there are two major classes of panel estimator approaches that can be employed. Namely, the fixed effects model and random effects model. In order to select the appropriate model which provide consistent estimates for this study, Hausman test was employed.

Table presents the Hausman specification test which suggests the fixed effects model was better than random effects model as the p-value (0.005), is less than 0.05 for dependent variableswhich

imply that the random effects model should be rejected and thus, the analysis is based on the fixed effects estimates.Conclusion: the Hausman test's null hypothesis that the RE estimator is consistent is rejected. i.e., banks fixed effects do appear to be correlated with the regressors'. We shall apply fixed effects model .So based on the result i.e the P-Value is less than 0.05 we will employ fixed method of panel data estimation.

\subsection{REgResSion RESUlts AND ANALYSIS}

The empirical findings from the econometric results on the effect of asset liability management on Profitability of banks in Ethiopia presented in this section. The section covers the empirical regression model used in this study and the results of the regression analysis. The following empirical model was used in order to identify the relationship between asset liability management and Profitability of banks in Ethiopia.

The result reports regression results between the dependent variable (NIM) and independent variables.

This section discusses in detail the analysis of the results for each explanatory variable and their importance in determining Profitability in private banks in Ethiopia. Furthermore, the discussion analyzes the statistical findings of the study in relation to the previous empirical evidences. Hence, the following discussions present the interpretation on the fixed effects model regression results and relationship between explanatory variables and profitability.

This section presents the empirical findings from the econometric results on the relation between asset liability management and bank profitability in Ethiopia. The section covers the empirical regression model used in this study and the results of the regression analysis.

Significant of the model is tested, accordingly, table 4.10 of Multiple regression indicated that the regression model predicts the outcome variable significantly with the p-value of $(0.000)$ and its shows the overall model applied was significantly good enough in predicting the outcome variable. It shows dependent variable (Net Interest Income) $\mathrm{R}^{2}$ is 68.79 percent explained by itsIndependent variables, which is a good one. To conclude, the regression model used for the study has explained the overall model signifying the study was not lost very important variables that affect the study output. The asset explanatory variables of this study were decomposed into explanatory variables as loans and advances (NLATA), deposits in foreign banks (DFBATA), and investments in security (IVEATA). As shown in the above table, the fixed effect regression result shows that all assets except loan and advance have positive effect on private commercial banks profitability. In other words, assets management has positive effect on commercial banks profitability. This finding coincides with the findings of Asiri (2007), Sufian and Habibulah (2009), and Miller and Noulas (1997), who found that assets management has positive effect on commercial banks profitability.

Loans and advances (NLATA): Interest income from loans and advances are the major source of revenue for commercial banks. The more the deposit that are transformed in to loans, the higher the profitability of banks due to interest rate on loans are much higher than interest expense on deposits. Therefore, the loans to total asset ratio of the sample banks during the studied period shows negative significant effect on profitability. It is indicated that Loans and advances had negative relationship with profitability and strongly statistically significant ( $\mathrm{p}$-value $=0.000$ ) at $1 \%$ significance level,because, there is a significant negative effect of the loan and advance on the profitability of private commercial banks in Ethiopia during the study period (2005-2017 G.C).This finding is contradict with Naceur et al. (2003) whoexplained that more deposits are transformed into loans for earning interest incomes from borrowers. This is inconsistent with the expected sign and not similar with the assumption which states there is a positive relationship between asset management proxy by loan and advance to asset ratio and profitability as measured by net interest income. The higher the interest rate margins, the higher profitsand banks are able to shield themselves against hazards of credit risk resulting from adverse selection and moral hazard. Kosmidou et al. (2004) also found loans and advances were the asset items which create profitability difference between banks. And it was also not similar with the actual sign. As a result, the null hypothesis : which states there is no significant relationship between ALM proxied by Loans \& advances to 
Asset ratio and profitability of core business operations of private commercial banks in Ethiopia was rejected. This implies that every 1 unit (birr) change (increase or decrease) in bank's loans \& advances ratio keeping the other thing constant has a resultant change of -3.223887 cents on the net interest income in different direction. This result also shows that a decrease in amount of loan advances to customers from deposit has a negative effect on profitability of Ethiopian banking industry. The possible reason could be that the interest income associated with loan advances was less than the costs or interest paid to depositors.

Deposits in foreign banks (DFBATA): is found to have positive and significant effect on regression equation conducted for commercial banks at $1 \%$ percent significant level in terms of interest income .But still has a significant positive effect on NII at 5\% significant level. This is consistent with the expected sign and similar with the assumption which states there is a positive relationship between asset management proxy by deposit with other banks to asset ratio and profitability as measured by net interest income. The amounts in this variable are composed of mainly deposits in foreign banks so the positive relation is attracted by the more interest income paid by foreign banks as compared to the saving interest rate. This implies that every $1 \%$ change (increase or decrease) in bank's deposits in foreign bank ratio keeping the other thing constant has a resultant change of $0.3288481 \%$ on the net interest income in the same direction. This result also shows that an increase in amount of deposit in foreign banks has a positive effect on profitability of Ethiopian banking industry. But since we are considering a $95 \%$ confidence level we take this variable as significant to affect profitability as measured by net interest income.

Investment in security (IVEATA): is found to be significant relation with net interest income . It is indicated that investments in security had positive relationship with profitability with strongly statistically significant $(\mathrm{p}$-value $=0.000)$ at $1 \%$ significance level. This result indicates that every $1 \%$ change (increase or decrease) in bank's f investments in security ratio keeping the other thing constant has a resultant change of 1.720594 cents on the net interest income in the same direction. The interest earned here is minimal due to in the reason that coupon bonds earn lower interest income (6\%) compared to loan $(9.5 \%)$.

Regarding the liability variables, the explanatory variables are decomposed as fixed deposit (FDATA), saving deposit (SDATA), demand deposit (DDATA). This decomposition is done by considering the characteristics of the liability and its maturity. Concerning the effect of deposits on profitability, even though it is the main source of funds for banks, the number one expense item for a banking sector is interest payment on saving and fixed deposits. Saving deposits are opened with a primary aim of encouraging saving so that banks pay a higher interest rate compared to demand deposits. Banks, then, can invest the money on areas that take, somewhat, longer pay back period than demand deposits. DDATAs (demand deposits) are opened, often, by businesses that require immediate cash so that the amount involved is large. The National Bank of Ethiopia (NBE) report on 2010 portray classification of time deposits on the basis of time bound as up to 1 year, 1-2 years and over 2 years. The average deposit interest rate on SDATA amongst other deposits is highest. A higher interest payment on time deposit is attributable to the arrangement that it is not payable on demand without the consent of the bank.

This study finds a negative but insignificant effect of fixed and saving deposit on private Ethiopian banks profitability as measured by net interest income.

Demand deposit (DDATA):Interest expense paid for demand deposits are the major expense item for private commercial banks. The more deposit acquired by the banks, the higher interest paid by banks. Therefore, the demand deposit to total asset ratio of the sample banks during the studied period shows positive and highly significant effect on profitability. It is indicated that demand deposits had positive relationship with profitability with statistically significant $(\mathrm{p}$-value $=0.008$ ) at $10 \%$ significance level. This finding is similar with Kosmidouet al (2004) who found that liability management plays its own pivotal role in contributing profitability difference among commercial banks and Asiri (2007) who mentioned that assets management positively and liabilities management negatively related to the profitability of Kuwaiti banks. Then, those variables are contradict to each others.

\section{CONCLUSION AND RECOMMENDATIONS Conclusions}

In order to cope with the changes in the environment, banks have been forced to effectively manage their asset and liability to mitigate various risks that arise due to mismatch between their assets and liabilities, Risk is inherent to any business, but it can be controlled to mitigate its effect on profitability. ALM involves a set of actions and procedures designed to control banks risks and financial positions. The core issue of Asset-Liability Management (ALM) is the bank's balance sheet and the main question is: Given a certain level of risk, government regulation, globalization, competitors, and alternative choices of investment, and liquidity and interest rate changes in the market, what should be the composition of a bank's assets and liabilities in order to maximize the bank's profit? Extensive researches attempted to identify the effects of asset liability management on profitability of firms. However, the findings of prior empirical studies have provided varying and in some 
cases contradicting evidence related to the effect of asset liability management on profitability. Furthermore, the majority of these studies have been conducted in developed countries.

In light of the above, the main objective of this study was to investigate the effect of asset liability management on profitability of core business operation of private commercial banks in Ethiopia, employing the SCA model. To achieve the intended objectives the study used quantitative approaches panel data analysis methodology. The panel data were collected from audited financial statements particularly balance sheets and income statements of a sample of seven banks over the time period from 2005-2017. The collected data were analyzed by employing a fixed effect model using statistical package "STATA 13 Version".

In order to conduct the empirical analysis, one dependent variable and six independent variables were selected and used by taking in to account the nature of banks operation. Net interest margin was taken as dependent variable, while the independent variables were loans \& advances to asset ratio, deposit in foreign banks to asset ratio, investment in security to asset ratio, saving deposit to asset ratio, fixed deposit to asset ratio, demand deposit to asset ratio.It was observed that $54.53 \%$ of banks interest income variation is explained by the above mentioned variables. The results of the fixed effect estimation model showed the existence of the following relationship between the variables.

The empirical findings of this study provide evidence that the profitability of private commercial banks in Ethiopia is positively affected by assets management. The significance of individual assets differs; loans and advances have the most significant effect on the profitability of private commercial banks followed by investments in security, deposit in foreign in banks, and does significantly affect private commercial banks profitability. This leads us to generalize that the spreads realized from loans and advance in the Ethiopian private commercial banking market is not attractive.

From the liability variables only demand deposit is the significant variable that positively affects profitability of private commercial banks. This may be due to the costliness of this source of fund. The saving and fixed deposits variable has negative and insignificant effect on private commercial banks profitability. This is due to the fact that commercial banks do not pay any interest for demand deposit but charge high service fees.

\section{Recommendations}

Overall these empirical results provide evidence that, the profitability of Ethiopian private commercial banks are shaped by composition of asset liability and macroeconomic variables that are not the direct result of a banks managerial decisions. So, policy makers and decision makers at the private commercial banks should give high concern and set direction in order to set the optimum composition of asset and liability which maximizes the bank profit.

Since, the loan component was found to be the most significant contributor towards bank profitability; private commercial banks should focus on loans rather than investment in securities, investment in subsidiaries and coupon bonds because, the banks earn relatively higher interest income from loans than investment in securities. On the other hand, in order to resist the challenges of credit risk, a more thorough analysis of the loans portfolio may be useful for the private commercial banks in structuring a sound, stable and profitable asset portfolio.

Since deposits are banks' primary sources of funds that they can be invested to generate income. The private commercial banks should make unreserved efforts to mobilize deposits that will meet the growing credit demand of the economy by implementing several deposit mobilization strategies which in return make the bank more profitable.

Private Commercial banks should take the necessary actions to increase its current account deposit, which create free funding from floats and contribute positively towards profitability. Thus, in order to secure from the almost nil cost current account deposits, private commercial banks should try to make their current account service attractive as much as possible. Thus, volume in regard to demand deposit should be a strategic tool for private commercial banks

To improve its profitability and at the same time to place themselves in a better position above other banks in a competition for deposits the so called deposit war.

As many literatures supports financial intermediation in Ethiopia is still in its early stages even by the standards of other low-income countries: in terms of unbanked society and many other metrics such as the total number of banks, banks contribution to GDP, bank accounts per person, branches per person, and bank credit per person are lower in Ethiopia compared

to other African countries. Thus, private commercial banks should focus to reach this unmet demand of finance.

\section{FURTHER RESEARCH DIRECTION}

This study is duly designed to test the effects of asset liability management on profitability of private banks in Ethiopia Therefore, the researcher would like to recommend future researchers to include and measure the effect 
of otherasset ,fixed asset, operational efficiency, income diversification, government regulation and policy ,real gross demostic product, market share and inflation in order to obtain reliable results.

\section{REFERENCES}

Alemayehu, G (2006). The Structure and Performance of Ethiopia's Financial Sector in the Preand Post Reform Period with a Special Focus on Banking Working paper 112/2006. UNU-WIDER. (C) UNU-WIDER .

Alper. D Anbar. A (2011) Bank specific and macroeconomic determinants of commercial bank profitability: Business and Economics Research Journal Volume 2(2). 139-152.

Athanasoglous P. et al., (2006), Bank-Specific, Industry- Specific and Macroeconomic Determinants of Bank Profitability, Bank of Greece Working paper, No. 25 Babes Bolyai University, FSEGA

Balachander ,K et. al, (1997),Determinants of commercial bank profitability in case of Malaysia; banks. Journal of Engineering economics Siauliuuniversitetas BIATEC, Volume XI, 1-12.

Bikker, J.A. \& Hu, H. (2002). Cyclical Patterns in Profits, Provisioning and Lending of Banks

Bobakova.V(2003) Raising the Profitability of Commercial Banks:Nardona Banka Slovenska

Bourke, P. (1989). Concentration and Other Determinants of Bank Profitability in Europe,

Buckle.M and Beccalli.E(2011) Principles of banking and finance: University of London

Charumathi, B. (2008), Asset Liability Management in Indian Banking Industry ; with special reference to Interest Rate Risk Management in ICICI Bank, World Congress on Engineering, July 2 - 4, London, UK.

Chambers, D., and Charnes, A. (1961).Inter-Temporal Analysis and Optimization of Bank Portfolios. Management Science

Cooper L.G and Nakanishi (2010) Market-share analysis: evaluating competitive marketing

Dash, M. and Pathak, R. (2011), "A Linear Programming Model for Assessing Asset-Liability Effectiveness: Kluwer Academic Publishers ISBN 0-89838-278-5

Ebisa, D.(2012). Post 1991 Era financial sector deregulations in Ethiopia. Basic Research econometric analysis. Review of Economics and Statistics, 1-52. Economics. USA, Vol 1(1),1-22.

Eshete, Z.S ,Tesome, K.W and Abebe, T.K, (2013).Competition in Ethiopian Banking Industry.

Fama, E. F. 1980. Banking in the theory of finance: Journal of Monetary Economics 6: 39-57.

Flamin.V, McDonald.C and Schumacher.L(2009). The Determinants of Commercial Bank

Gul.S, Irshad.F and Zaman.K (2011). Factors affecting bank profitability in pakistan; The

Gup, B. E., and Brooks, R. (1993), Interest Rate Risk Management, Irwin Professional Publishing, B Burr Ridge.

Haron. S. (2004)Determinants of Islamic bank profitability:Global Journal of Finance and

Hester, D. D, and Zoellner, J. F. (1966). The relation between bank portfolios and earnings: an International Programmes, Stewart House p68-69

Hester, D. D., \&Zoellner, J. F. (1966). The relation between bank portfolios and earnings: an econometric analysis, Review of Economics and Statistics 48.

Joseph F. Sinkey, Jr., (1998), —Commercial Bank Financial Management - In the Financial Services Industry\|, Fifth Edition, Prentice-Hall International Inc., New Jersey Journal of Agricultural Science and Review ISSN 2315-6880 Vol. 1(4), 81-87.

KatarzynaZawalinska(1999), Asset and Liabilities Management. The Institutional Approach to ALM by Commercial Banks in Poland: a Special Focus on Risk Management, Center for Social and Economic Research.

Kavitha, N.(2012) Asset Liability Management of Scheduled Commercial: BanksInternational Journal of Marketing and TechnologyVo2, Issue 4, 20-44.

Kosmidou, K., and Zopoundis, C. (2001) "Measurement of Bank Performances in Greece." South-Eastern European Journal of Economics 1

Kumar, M.(2013). Liquidity risk management in bank: university of Delhi No 3

Kwast, M.L, and Rose, J. T. (1982). Pricing, operating efficiency, and profitability among

Large commercial banks.Journal Of Banking And Finance 6, 233-254.

Lileikiene.A.(2008) Chosen strategies of asset and liability management in commercial Management in Banks," ICFAI Journal of Risk Management mathematical modeling for bank:Journal of Basic and Applied Scientific Research 3(1) 484-493.

Mauri, A. (2003), Origins and early developments of banking in Ethiopia, Working Paper (04)

Mihail. I (2011)How does assets-liabilities management affects the profitability of banks;

Muhammad A. S \& Mohammad Z. H(2009)., Impact of Asset and Liability Management on Profitability: A study on public vs private commercial banks in Bangladesh, Jahangitnagar University, Dhaka, Bangladesh \&Monash University, Melbourne, Australia.multimedia university.15-18.

Naderi, S, Minouei, M and Gashti ,H.P(2013). Asset and liability optimal management

NBE Directives No.SBB/9/95.(n.d.).National Bank of Ethiopia Licensing and Supervision of Banking Business 
Proclamation No.84/1994 (1994). Minimum Capital Requirement for Banks [Online], available at http://www.nbe.gov.et.

NBE.(2015/16).Annual Report. Addis Ababa: National Bank of Ethiopia.

Oguzsoy, C. B., \&Guven, S. (1997). Thoery and Methodology: Bank asset and liabilitymanagement under uncertainty European Journal of Operational Research, 102, Production Economics, 43, 67-73.Profitability in Sub-Saharan Africa:IMF Working Paper. Retrieved from http://www.lschumacher@imf.org profitability: Business and Economics Research Journal Volume 2(2).139-152.

Ramlall, I. (2009), Bank Specific, Industry Specific and Macroeconomic Determinants of Profitability in Taiwanese Banking System: Under Panel Data Estimation, International Research Journal of finance and EconomicsRomanian Economic Journal:XIV(39) 64

Rose, P.S. \& Hudgins, S.C. (2006). Bank Management \& Financial Services, (6th Ed.) McGraw-Hill, New York. Sayeed, M.A. and Hoque,M.Z (2008).Impact of Asset and Liability Management on Profitability, Jahangitnagar University, Dhaka, Bangladesh.

Singh, K. (2013) asset liability management in banks .AIMA Journal of Management \& Research, May 2013, Volume 7.

Sinkey, Jr. \& Joseph, F. (1992).Commercial Bank Financial Management, In the Financial-Service Industry, (4thEd.), Macmillan Publishing Company, Ontario.South-Eastern European Journal of Economics 1

Tamiru.B.(2013) Impacts of asset liability management ;Research Journal of Finance and

Uyemura, D.G. \& Van Deventer, D.R. (2003).Financial Risk Management in Banking, McGraw - Hill, New York, NY

Vaidyanathan.R.(1999). Asset-liability management: journal of management, 29(1), 39-48.

Vasiliou, D. (1996). Linking profits to Greek production management.International Journal of

Zawalinska,K. (1999). Asset and Liability Management. The Institutional Approach to ALM by Commercial Banks in Poland: a Special Focus on Risk Management, CASE - Center for Social Science Research, Warsaw.

Zopounidis, C. (2001). Multicriteria decision aid in financial management, European Journal of Operational R

\section{BOOKS}

Brooks.C(2008) Introductory econometrics for finance :2nd edition. Cambridge University Press Chandra, P.(2003) Fundamental s of financial management; $3^{\text {rd }}$ edition: New Delhi Tata MC Gran Hill.

Chakrabanti A.N. (2005) Financial management: Indian institute of banking Ance. MUMBAI.

Gujarati N.D (2004) Basic econometrics, $4^{\text {th }}$ Edition McGraw-Hill Companies

Mishikin S. F. (2004), The Economics of Money, Banking and Financial Markets (7th ed.), Addison-Wesley Publisher, USA.

Muhammad A. S \& Mohammad Z. H(2008)., Impact of Asset and Liability Management on Profitability: A study on public vs private commercial banks in Bangladesh, Jahangitnagar University, Dhaka, Bangladesh \& Monash University, Melbourne, Australia

Mulvey and Vladimirou(1992) Asset management, Liability management, Financial securities, Market prices, Investment risk, Aggregation, Cash flow, Interest rates, Dynamic modeling, Risk aversion.

Somashekar.N.( 2009) Banking: New Delhi. New Age International (P) Ltd.

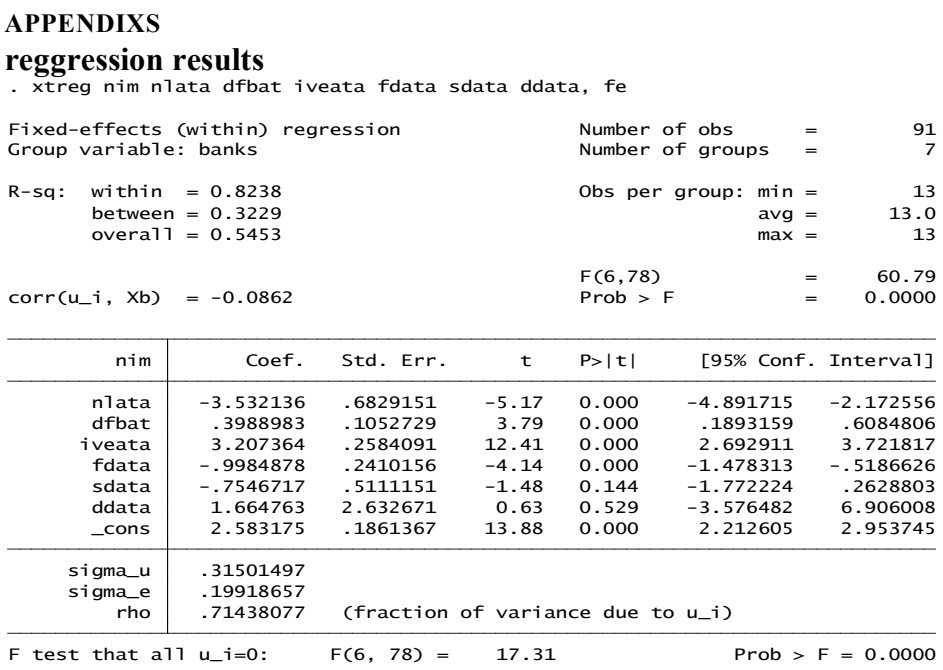

